Pesq. Vet. Bras. 37(4):389-394, abril 2017 DOI: $10.1590 /$ S0100-736X2017000400014

\title{
Reference values for selected ophthalmic tests of the blue-and-yellow macaw (Ara ararauna) ${ }^{1}$
}

\author{
Mário Sérgio A. Falcão², Rafael V. Monteiro², Clarissa M. Carvalho², Hudson H. de \\ Andrade $^{2}$ and Paula D. Galera ${ }^{2 *}$
}

\begin{abstract}
Falcão M.S.A., Monteiro R.V., Carvalho C.M., De Andrade H.H. \& Galera P.D. 2017. Reference values for select ophthalmic tests of the blue-and-yellow macaw (Ara araruna). Pesquisa Veterinária Brasileira 37(4):389-394. Departamento de Cirurgia de Pequenos Animais, Faculdade de Agronomia e Medicina Veterinária, Universidade de Brasília, Campus Universitário Darcy Ribeiro, Avenida L4 Norte, Asa Norte, Brasília, DF 70910-900, Brazil. E-mail: dra.paulagalera@gmail.com

The aim of this study was to establish reference values for selected ophthalmic diagnostic tests in healthy blue-and-yellow macaws. We investigated a total of 35 adult macaws (70 eyes) of undetermined sex and with an average weight of $1 \mathrm{~kg}$, who were living in captivity in the Federal District, Brazil. Tear production using the Schirmer tear test (STT), normal conjunctival flora, intraocular pressure (IOP) using a rebound tonometer and horizontal palpebral fissure length (HPFL) were evaluated. In this study, $84.1 \%$ of samples were positive for microbial growth. Bacteria, fungi and yeasts were isolated, and Staphylococcus spp. (21.9\%) and Bacillus spp. (26.8\%) were the most frequently isolated microorganisms. The mean value for STT was $7.6 \pm 4.6 \mathrm{~mm} / \mathrm{min}$ in the right eye (OD) and $6.6 \pm 4.4 \mathrm{~mm} / \mathrm{min}$ in the left eye (OS) (median $=7,11 \pm 0,76 \mathrm{~mm} / \mathrm{min}$ ). Mean IOP was $11.4 \pm 2.5 \mathrm{~mm} \mathrm{Hg}$ OD and $11.6 \pm 1.8 \mathrm{~mm} \mathrm{Hg}$ OS (median $=11.49 \pm 0.22 \mathrm{~mm} \mathrm{Hg}$ ), prior to anesthesia, and $7.6 \pm 2.4 \mathrm{~mm} \mathrm{Hg}$ OD and $7.8 \pm 1.8 \mathrm{~mm} \mathrm{Hg}$ OS (median $7.71 \pm 0.08 \mathrm{mmHg}$ ) after anesthesia. The IOP was significantly lower when the animals were under anesthesia as compared to when they were conscious $(\mathrm{p} \leq 0.05)$. Horizontal palpebral fissure length was $11.7 \pm 0.1 \mathrm{~mm}$ OD and $11.8 \pm 0.1 \mathrm{~mm}$ OS (median $=11.72 \pm 0.07 \mathrm{~mm}$ ). The STT showed a positive correlation with palpebral fissure measurement for this species. These selected ophthalmic reference values will be particularly useful in diagnosing pathological changes in the eyes of blue-and-yellow macaws.
\end{abstract}

INDEX TERMS: Ophthalmic tests, blue-and-yellow macaw, Ara araruna, birds, Schirmer tear test, intraocular pressure, normal microflora.

RESUMO-- [Valores de referência para selecionados testes oftálmicos para a arara canindé (Ara araruna).] Objetivou-se determinar os valores normais para testes oftálmicos diagnósticos selecionados para a Arara Canindé. Trinta e cinco Ara ararauna (70 olhos), de sexo indeterminado, adultas, com peso médio de $1 \mathrm{~kg}$ e provenientes de cativeiro no Distrito Federal, foram avaliadas. Aferiram-se a produção lacrimal pelo Teste lacrimal de Schirmer (TLS), a avaliação microbiológica da conjuntiva ocular, a pressão intra-ocular (PIO) utilizando a tonometria de rebote e o comprimento

\footnotetext{
${ }^{1}$ Received on March 20, 2016.

Accepted for publication on October 10, 2016.

${ }^{2}$ Faculdade de Agronomia e Medicina Veterinária, Universidade de Brasília, Avenida L4 Norte, Asa Norte, Brasília, DF 95320-000, Brazil. *Corresponding author: dra.paulagalera@gmail.com
}

horizontal da rima palpebral Neste estudo $84.1 \%$ das amostras analisadas foram positivas para crescimento microbiológico. Bactérias, fungos e hifas foram isolados e Staphylococcus spp. (21.9\%) e Bacillus spp. (26.8\%) foram isolados mais frequentemente. Os valores médios do teste de Lacrimal de Schirmer (TLS) foram de $7.6 \pm 4.6$ e $6.6 \pm 4.4 \mathrm{~mm} / \mathrm{min}$ para olhos direito (OD) e esquerdo (OE), respectivamente (média $=7,11 \pm 0,76 \mathrm{~mm} / \mathrm{min}$ ). A pressão intraocular média foi de $11.4 \pm 2.5$ (OD) e $11.6 \pm 1.8 \mathrm{mmHg}(\mathrm{OE})$ anteriormente à anestesia (média 11,49 $\pm 0,22 \mathrm{mmHg}$ ) e $7.6 \pm 2.4 \mathrm{mmHg}$ (OD) e $7.8 \pm 1.8 \mathrm{~mm} \mathrm{Hg}(\mathrm{OE})$ (média 7,71 $\pm 0,08 \mathrm{~mm} \mathrm{Hg}$ ) após a anestesia, verificando-se que a PIO foi significativamente menor quando os animais se encontravam sob anestesia comparativamente ao momento em que não estavam anestesiados. 0 comprimento horizontal da rima horizontal palpebral foi de $11.7 \pm 0.1 \mathrm{~mm}$ OD e de $11.8 \pm 0.1 \mathrm{~mm}$ OE (média 
$11,72 \pm 0,07 \mathrm{~mm}$ ). Verificou-se correlação positiva do TLS com o comprimento da fissura palpebral para a espécie estudada. Estes valores de referencia serão úteis no diagnóstico de alterações oculares da Arara Canindé.

TERMOS DE INDEXAÇÃO: Testes oftálmicos, arara canindé, Ara Araruna, aves, teste lacrimal de Schirmer, pressão intra-ocular, microflora normal.

\section{INTRODUCTION}

The order Psittaciformes is classified into three large families: Loridae, Cacatuidae and Psittacidae (Sick 2001). Brazil is one of the countries with the highest number of Psittaciformes in the world (Hvenegaard et al. 2009), and Ara ararauna (blue-and-yellow macaw) belongs to this order (Valle et al. 2008). Their specific features allow their ready identification, such as the following: short beak with wide base adapted for breaking seeds and fruits, particularly with movable jaw; large, broad head and peri-ocular region with no feathers; short neck; zygodactyl feet and short legs (Sick 2001, Godoy 2007), blue feathers on the dorsal side, yellow feathers on the ventral side, black feathers on the neck and small rows on the face (Bianchi 1998).

Ara araruna weighs on average 1 to $1.1 \mathrm{~kg}$ (Godoy 2007, Santos \& Ragusa-Netto 2014), and the body length is 80 to $86 \mathrm{~cm}$ (Sick 2001, Gwynne et al. 2010). These macaws reach sexual maturity at five years of age (Francisco \& Moreira 2012) and build their nests in tree trunks. They have a clutch of one to five eggs (Bianchi 1998) and an incubation time of 26 days (Bianchi 1998, Francisco \& Moreira 2012). There are reports that these macaws can live up to 75 years in captivity (Godoy 2007). They feed mainly on seeds and fruits, and like other parrots (Godoy 2007), they are one of the species most commonly found in homes and raised by private bird breeders (Bianchi 1998).

Birds are considered animals with great capabilities and visual acuity, where these factors are important for breeding, feeding and flight (Hart 2002, Reuter et al. 2011, Williams 2012, Rauscher et al. 2013). However, while their ocular physiology is similar compared to mammals, there are peculiarities that can directly influence evaluation in these species (Williams 2012).

Eye and eyelid lesions are a common finding in birds (Fernandez \& Dubielzig 2014), and ocular and periocular trauma account for about $30 \%$ of lesions, mainly due to collisions with windows, cars, trees and buildings (Seruca et al. 2012). Large parrots often present with periorbital diseases, secondary to upper respiratory tract infections, rhinitis and chronic sinusitis (Hvenegaard et al. 2009). Parrots are often kept as pets, and have received increasing ophthalmic care by veterinarians over the last twenty years (Bayón et al. 2007).

Although the ophthalmic examination used in birds is the same as for other animal species, ocular disease is likely to be underdiagnosed in some species, at least in part because of limited proven diagnostic methods and lack of published scientific data (Smith et al. 2015). Tear production and IOP measurements should be routine in the ocular examination (Williams 2012). Although the Schirmer tear test (STT), tonometry and conjunctival flora have been studied in birds (Harris et al. 2008, Kern \& Colitz 2013), there is a lack of normal values for Ara ararauna. This research aimed to stablish reference values for these ophthalmic tests for this species.

\section{MATHERIALS AND METHODS}

\section{Ethics statement}

The study was approved by Ethics Committee (No. 446763/ 2014) and conducted in accordance with the Association for Research in Vision and Ophthalmology (ARVO) Ethical Principles (Statement for the Use of Animals in Ophthalmic and Vision Research).

\section{Animals}

Thirty-five macaws (Ara ararauna) were subjected to clinical and laboratory evaluation (hematology and biochemistry). The birds were adults, of undetermined sex and without clinical or ophthalmic problems; they had an average weight of $1 \mathrm{~kg}$. All animals were kept in captivity by IBAMA (Brazilian Institute of Environment and Renewable Natural Resources), in the Federal District, Brazil. The birds were examined and subsequently returned to the wild.

For data collection, the animals were captured individually in the enclosures with the help of a hand net and transported to the examination room, where there were kept at rest for at least five minutes to minimize the stress arising from their capture. Ophthalmic evaluation was performed by inhalation anesthesia. Only intraocular pressure (IOP) was measured before and after anesthesia. This research was conducted as a pilot study with two macaws (four eyes) to check the feasibility of carrying out the STT.

The birds were physically confined upright, positioning the fingers behind the head and on the beak, and subjected to general anesthesia with the aid of a mask with isoflurane delivered in $100 \%$ oxygen. Every thirty seconds, the anesthetic was raised by $0.5 \mathrm{vol} \%$, to obtain anesthesia. The birds reached an anesthetic plane after approximately four minutes of induction with mask, and the mean concentration of isoflurane was $3.5 \mathrm{vol} \%$. Anesthesia was maintained in open circuit (HP Slim ${ }^{\circledR}$ with vaporizer calibrated for isoflurane), with mask for fifteen minutes.

\section{Ophthalmic evaluation}

Under general inhalation anesthesia, ocular surface was examined by slit-lamp biomicroscopy (Kowa SL-15 ${ }^{\circledR}$ ) followed by the following tests: STT (Ophthalmos Fórmulas, São Paulo, SP, Brazil); corneo-conjunctival swab for microbiological analysis; rebound tonometry (Tonovet ${ }^{\circledR}$ Tonometer, USA); and measurement of the horizontal palpebral fissure length (HPFL) with a digital caliper (150mm capacity with $0.01 \mathrm{~mm}$ resolution) (Fig.1). Only tonometry was done before and after anesthetic induction. All ophthalmic parameters were determined by the same investigator.

Schirmer tear test (STT). Once reaching an anesthetic plane, the macaws were positioned in right lateral decubitus, and the STT was performed. The STT strips were inserted at the bottom of the conjunctival sac of the lower eyelid of both eyes (Figure 1B) and left there for one minute.

Culture. For microbiological sampling, sterile swabs of cotton wool were inserted in the lower conjunctival sac of both eyes of macaws, avoiding contact with the eyelid (Fig.1D). After sampling, the swab was placed in Stuart medium and the material sent to the Microbiology Laboratory, School of Agronomy and Veterinary Medicine, at University of Brasilia. The culture of microorganisms was carried out in Petri dishes with blood agar incubated at $37^{\circ} \mathrm{C}$ under aerobic conditions, for 24 to $48 \mathrm{~h}$. After growth, the colonies were identified on the basis of the presence or absence of 

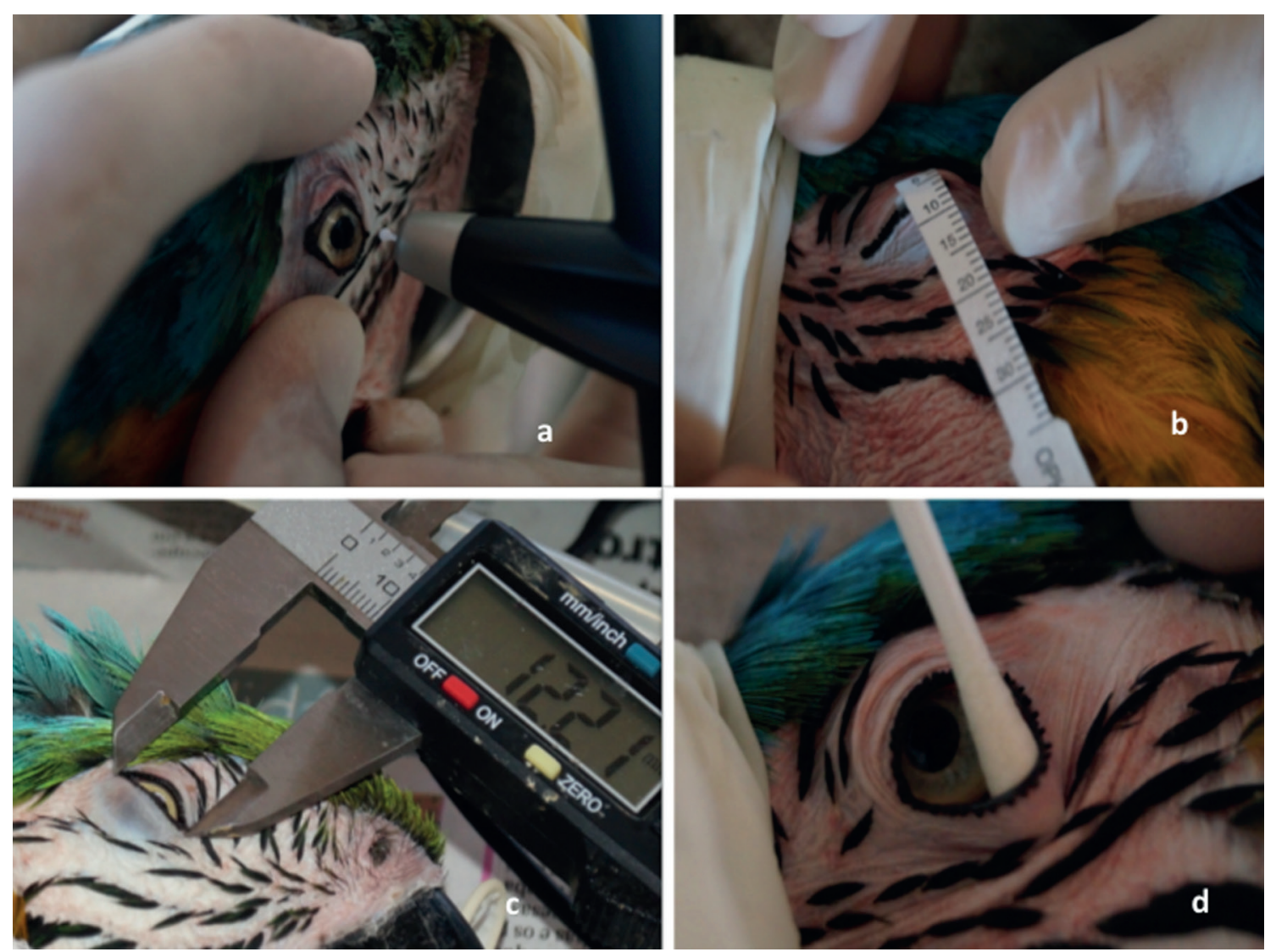

Fig.1. (a) Ophthalmic evaluation of Blue and yellow macaw, which was subjected to rebound tonometry, (b) STT measurement of palpebral fissure length (PFL), (c) with digital caliper, and (d) collection of sample with swab for microbiological analysis.

hemolysis in blood agar and the morphological and biochemical characteristics according to routine laboratory techniques.

Tonometry. The birds were physically confined in an upright position, placing the fingers behind the head and on the beak to measure IOP (Fig.1A), avoiding excessive pressure on the cervical region. A new measurement of IOP was taken fifteen minutes after induction of anesthesia and maintenance, in the same position as before.

Palpebral fissure length (PFL). Palpebral fissure length was determined using a digital caliper, measuring the space between lateral and medial commissures, with the eyelids closed (Fig.1C).

After completion of the ophthalmic examination and after recovery from anesthesia, when they could stand steady with reestablished body temperature, animals were returned to their respective enclosures.

\section{Statistical analysis}

Statistical analysis was carried out with commercially available software (GraphPad Prism ${ }^{\circledR}$ ). The values obtained for IOP were compared between the right (OD) and left (OS) eye, using the nonparametric Wilcoxon test, because a normal distribution was not established. STT and HPFL results were analyzed using a paired t-test. Differences were considered significant when $\mathrm{p} \leq 0.05$. OD and OS were considered as independent measurements, and we determined if HPFL measurements had an influence on STT and IOP according to the Pearson correlation test.

\section{RESULTS}

Results are listed on Table 1 and 2 . The mean values for STT were $7.6 \pm 4.6$ and $6.6 \pm 4.4 \mathrm{~mm} / \mathrm{min}$ for OD and OS, respectively, and were not significantly different $(p=0.24)$.
Microbiological analysis detected positive samples in $84 \%$ of eyes, while $15 \%$ showed no microbial growth. The positive samples showed the growth of Gram-positive and -negative bacteria, and fungi as well. The Gram-positive

Table 1. Values of Schirmer tear test, intraocular pressure before (IOPb) and after (IOPa) anesthesia and horizontal palpebral fissure length (HPFL) in Ara ararauna (mean \pm standard deviation)

\begin{tabular}{lccccc}
\hline & OD & OS & Median & \multicolumn{2}{c}{ Range OD Range OS } \\
\hline STT (mm/min) & $7.6 \pm 4.6$ & $6.6 \pm 4.4$ & $7.11 \pm 0.76$ & $0-23$ & $0-19$ \\
IOPb (mmHg) & $11.4 \pm 2.5$ & $11.6 \pm 1.8$ & $11.49 \pm 0.22$ & $8-20$ & $7-20$ \\
IOPa (mmHg) & $7.6 \pm 2.4$ & $7.8 \pm 1.8$ & $7.71 \pm 0.08$ & $4-13$ & $3-13$ \\
Eyelid length (mm) & $11.7 \pm 0.1$ & $11.8 \pm 0.1$ & $11.72 \pm 0.07$ & $10-12.9$ & $10-14$
\end{tabular}

Table 2. Frequency of microorganisms isolated in seventy eyes of Ara ararauna

\begin{tabular}{ccc}
\hline Microorganisms isolated & $\begin{array}{c}\text { Frequency of } \\
\text { microorganisms } \\
\text { isolated }\end{array}$ & $\begin{array}{c}\text { Number of } \\
\text { microorganisms } \\
\text { isolated }\end{array}$ \\
\hline
\end{tabular}

Gram-positives

Bacillus spp.

Staphylococcus spp.

Staphylococcus aureus

Streptococcus pyogenes

Gram-negatives

Escherichia coli

Fungi

Absence of microbial growth

Total

$\begin{array}{cc}22 \% & 18 \\ 20 \% & 17 \\ 6 \% & 5 \\ 1 \% & 1 \\ & \\ 6 \% & 5 \\ 28 \% & 23 \\ 15 \% & 13 \\ 100 \% & 82\end{array}$


bacterium isolated the most often was Bacillus $s p$ and the most common Gram-negative one was Escherichia coli, as described in Table 2.

Intraocular pressure values were $11.4 \pm 2.5$ and $11.6 \pm 1.8 \mathrm{mmHg}$ for OD and OS, respectively, showing no statistical difference between the means $(p=0.39)$. However, we found a statistically significant lower IOP in both eyes $(p=0.0001)$ with inhalation anesthesia $(7.6 \pm 2.4$ and $7.8 \pm 1.8 \mathrm{~mm} \mathrm{Hg})$.

The mean HPFL values were $11.7 \pm 0.1 \mathrm{~mm}$ (OD) and $11.8 \pm 0.1 \mathrm{~mm}(\mathrm{OS})$, with no statistical differences between them $(\mathrm{p}=0.18)$ (Table 1$)$.

\section{DISCUSSION}

The visual capacity of birds influences directly their behavior, and this is related to reproductive characteristics, flight and feeding (Hart 2002, Burton 2008). An efficient visual system adapted to different situations depends on important anatomical features. Particular features can be observed, such as the position of the eyeball in the orbit and the ratio of anterior and posterior segment, which influences the axis and visual acuity (Martin \& Shaw 2010). Anatomical and functional peculiarities result in changes in capacity of visual accommodation and physiological differences that influence directly the evaluation and parameters of ophthalmic tests (Kern \& Colitz 2013).

Although the literature notes that the standard strip (5 mm wide) is often too large to use in the eyes of most birds (Korbel \& Leitenstorfer 1998) and that tear assessment in birds with small eyes using the STT presents difficulties in its implementation (Williams 2012), this was not observed in the macaws evaluated in this study. This was determined in a pilot study with two macaws (four eyes) to check the feasibility of using the STT, where the eyes of the macaws were not considered small.

We found it easy to insert the strip into the conjunctival sac, but the birds did not allow it to remain in place, demonstrating vocalization and excessive agitation. Subsequently, constant movement of the nictitating membrane could be seen, until complete removal of the test strip, preventing the strip from remaining in place long enough for the test to be performed. As general restraint induces considerable stress, some clinical and ophthalmic tests are facilitated in birds by the use of inhalation anesthesia (Willis \& Wilkie 1999), and the STT was carried out immediately after inhalation anesthesia. We did attempt to mimic the real situation in which the animals would be evaluated in routine care, obtaining normal values for STT I. It is noteworthy that the sample showed phenotypic homogeneity, and with a substantial number of animals for this species, the results should be reliable. Although the STT was conducted shortly after anesthesia, we cannot rule out the influence of the drug used on the results obtained, since anesthetics lead to a decrease in tear production (Girolamo et al. 2013).

In a study conducted by Korbel \& Leitenstorfer (1998) with 255 birds of 42 different species, STT values were described for Psittaciformes with the use of $5 \mathrm{~mm}$-wide standard strips $(3.2 \pm 2.7 \mathrm{~mm} / \mathrm{min}$ STT I and $7.5 \pm 2.6 \mathrm{~mm} / \mathrm{min}$ STT II). Values were also reported for Psittaciformes using the $4-\mathrm{mm}$ modified strip $(1.7 \pm 1.4 \mathrm{~mm} / \mathrm{min}$ for STT I and $4.5 \pm 2.8 \mathrm{~mm} / \mathrm{min}$ for STT II), for Falconiformes with a $5-\mathrm{mm}$ strip $(2.0 \pm 1.7 \mathrm{~mm} / \mathrm{min}$ STT I and $4.2 \pm 3.1 \mathrm{STT}$ II), and for Accipitriformes with a 5 -mm strip $(10.7 \pm 4 \mathrm{~mm} / \mathrm{min}$ STT I and $11.5 \pm 5.4 \mathrm{~mm} / \mathrm{min})$. The median values observed for macaws $(7.11 \pm 0.76 \mathrm{~mm} / \mathrm{min})$ were higher than that previously reported for Psittaciformes (Korbel \& Leitenstorfer 1998), probably because of a large variety of species evaluated, and also higher than that found in other birds, but closest to that for an African grey parrot, a large Psittaciforme $(8.0 \pm 1.5 \mathrm{~mm} / \mathrm{min})$ with a $4-\mathrm{mm}$ strip (Williams 1994).

Three macaws had STT values equal to zero, and in one of them this value was observed in both eyes. Since the birds studied showed normal examination findings and since there are scarce reports in the literature of cases of keratoconjunctivitis sicca in birds (Barsotti et al. 2013), it is possible that such values may be related to anesthesia or to individual variation. In birds, the main cause of decreased tear production is neurogenic related to trauma and not to dry eye syndrome, unlike what occurs in dogs (Barsotti et al. 2013). In a colony of screech owls (Megascops asio), low STT values have been described and correlated with a small or even absent orbital lacrimal gland (Harris et al. 2008). Therefore, to establish a standard test for lacrimal assessment in birds can be difficult due to large anatomical and physiological differences in the tear production apparatus and lacrimal drainage between species (Smith et al. 2015).

The conjunctival microbiota has been studied in different mammals and wild animals, to guide treatment based on a presumed microbiological flora (Moore \& Nasisse 1999). In clinically normal birds, about $83 \%$ of single agents are bacteria, and in parrots, Staphylococcus and Corynebacterium are prevalent (Dupont et al. 1994, Willis \& Wilkie 1999). Corroborating the literature (Dupont et al. 1994), we found that $84.1 \%$ of the samples analyzed showed positive growth. However, $56.1 \%$ showed bacterial growth less than that described by Willis \& Wilkie (1999) but similar to what was reported by Zenoble et al. (1983) (59\%). Staphylococcus spp. and Bacillus spp. were the most isolated organisms (Table 2). Bacillus spp. are commonly isolated in reptiles (Somma et al. 2015) and in dogs (Meekins et al. 2015b). Although there was a higher prevalence of Gram-positives, corroborating the findings of Bayón et al. (2007), Escherichia coli accounted for $6.1 \%$ of the observed bacterial flora, higher than usually described but as frequently as bacteria isolated from the eyes of owls (Asio clamator) (Rodarte-Almeida et al. 2013) and flamingos (Meekins et al. 2015a). Gram-negative bacteria are rare in birds, and they usually represent about $1 \%$ of the samples (Bayón et al. 2007). The presence of yeast and fungi was also observed, which is not usually reported in birds (Dupont et al. 1994, Hoppes et al. 2000) but is common in horses (Sgorbini et al. 2008). The presence of fungi may be of transitory nature, due to the environment and exposure, which explains its low incidence, where they are more often isolated in cattle and horses, whose environment is richer in organic material (Dupont et al. 1994, Hoppes et al. 2000, Sgorbini et al. 2008, Meekins et al. 2015b). Yeasts are common isolates from fecal samples of birds and are 
not associated with clinical disease but may result from local contamination (Garcia et al. 2007). It was found that the normal microflora of the conjunctival sac of macaws is composed of a broad spectrum of microorganisms, including bacteria, fungi and yeasts. Factors such as season, geography, nutrition, population density and contact with other animals can influence these results (Swinger et al. 2009), highlighting the importance of determining the local flora in accordance with the region. Knowledge of specific normal ocular findings for each species, as well as reference values for diagnostic tests, is essential for comparative veterinary ophthalmology (Bliss et al. 2015).

All birds in the study tolerated the measurement of IOP without the need for general anesthesia or forceful restraint. We avoided the use of excessive pressure on the cervical region, so that no abrupt changes would be induced in venous return and consequent increase in IOP in an iatrogenic way (Pauli et al. 2006).

Rebound tonometer was designed for use in animals with small eyes and has recently been used in birds, such as bald eagle (21.5 $\pm 1.7 \mathrm{~mm} \mathrm{Hg}$ ) (Kuhn et al. 2013), Megascops asio $(11 \pm 1.9 \mathrm{~mm} \mathrm{Hg})$ (Harris et al. 2008), Spheniscus dermersus $(31.77 \pm 3.3 \mathrm{~mm} \mathrm{Hg}$ ) (Gonzalez-Alonso-Alegre et al. 2015), Bubo bubo (10:45 $\pm 1.64 \mathrm{~mm} \mathrm{Hg}$ ) (Jeong et al. 2007) and Phoenicopterus ruber ruber $(9.5 \pm 1.7 \mathrm{~mm} \mathrm{Hg})$ (Meekins et al. 2015a). Rebound tonometer reference values overestimate IOP compared to applanation tonometry in Eurasian eagle owls (Jeong et al. 2007). Testing the accuracy and reproducibility of IOP measurements obtained with the TonoVet rebound tonometer, Reuter et al. (2010) reported that in chickens, results with this device correlated less with manometric values than in dogs, cats and horses. However, since the survey was conducted in enucleated eyes, the influence of bony and cartilaginous components of scleral processes was not considered. In Ara ararauna, the scleral bones show variations in quantity, compared to other parrots, having 12 of 13 ossicles (Lima et al. 2009), and in the shape of the open orbit, besides a smaller zygomatic bone (Machado et al. 2006).

The discrepancy in values described for the different species of birds is due to species-specific particularities of the ocular anatomy (Reuter et al. 2010), such as size of the eye and corneal thickness (Kuhn et al. 2013), emphasizing the need to establish values for specific species, without extrapolating from one species to another. Until now, there had been no rebound tonometry values reported in the literature for A. ararauna.

Despite that macaws tolerated tonometry without chemical restraint, factors such as excessive vocalization, stress from physical restraint and the very restless temperament of A. ararauna (Smith et al. 2015) prompted us to use inhalation anesthesia (as previously described), which allowed us to also assess the direct influence of anesthesia on IOP. Inhaled anesthetics are described as drugs of choice for birds, given their safety and fast anesthetic induction and recovery, and of these, isoflurane has been the most used (Nicolau et al. 2002, Lichtenberger \& Ko 2007). The birds enter an anesthetic plane in approximately four minutes with constant vaporization (3.5 vol\%). All animals showed good recovery, which was a concern, not only for the animal but mainly because there was a commitment to return it to the wild.

The values obtained in the second IOP measurement (15 minutes after the initial measurement and under anesthesia) were statistically lower compared to the initial values. The anesthetics might have decreased IOP by facilitating the drainage of the aqueous humor (Murphy et al. 1995), by the relaxation of extraocular muscles, suppression of the central nervous system and neurovascular control of IOP (McMurphy et al. 2004). Since there is a close relationship between the ciliary muscles and the drainage of the aqueous humor by the uveal-scleral pathway (Williams 2012), it is possible that muscle relaxation provided by anesthesia can influence more directly IOP in most birds than in other species, considering the significant decrease in IOP reported in rats (Johnson et al. 2008, Ding et al. 2011) and chickens (Willis \& Wilkie 1999) anesthetized with inhalant gas.

\section{CONCLUSION}

The results obtained provide reference values that can be used for Ara ararauna. These reference values will be useful in the diagnosis of ocular changes in the blue-and yellow macaw.

Acknowledgements.- We thank Spazen Arte Vivenda for allowing us to conduct the study in animals under their care. Dr. A. Leyva helped with English translation and editing of the manuscript.

\section{REFERENCES}

Barsotti G., Briganti A., Spratte J.R., Ceccherelli R. \& Bregui G. 2013. Schirmer tear test type I readings and intraocular pressure values assessed by applanation tonometry (Tonopen ${ }^{\circledR} \mathrm{XL}$ ) in normal eyes of four European species of birds of prey. Vet. Ophthalmol. 16(5):365-369.

Bayón A., Almela R.M. \& Talavera J. 2007. Avian ophthalmology. Eur. J. Comp. Anim. Med. 17(3):253-265.

Bianchi C.A.C. 1998. Biologia reprodutiva da Arara Canindé (Ara ararauna, Psittacidae) no Parque Nacional das Emas, GO. Dissertação de Mestrado em Ecologia, Instituto de Biologia, Universidade de Brasília, Brasília. 69p.

Bliss C.D., Aquino S. \& Woodhouse S. 2015. Ocular findings and reference values for selected ophthalmic diagnostic tests in the macaroni penguin (Eudyptes chrysolophus) and southern rockhopper penguin (Eudyptes chrysocome). Vet. Ophthalmol. 18(Suppl.1):86-93.

Burton R.F. 2008. The scaling of eye size in adult birds: Relationship to brain, head and body sizes. Vision Res. 48(22):2345-2351.

Ding C., Wang P. \& Tian N. 2011. Effect of general anesthetics on IOP in elevated IOP mouse model. Exp. Eye Res. 92(6):512-520.

Dupont C., Carrier M. \& Higgins R. 1994. Bacterial and fungal flora in healthy eyes of birds of prey. Can. Vet. J. 35(11):699-701.

Fernandez J.R.-R. \& Dubielzig R.R. 2014. Ocular and eyelid neoplasia in birds: 15 cases (1982-2011). Vet. Ophthalmol. 18(Suppl.1):1-6.

Francisco L.R. \& Moreira N. 2012. Manejo, reprodução e conservação de psitacídeos brasileiros. Revta Bras. Reprod. Anim. 36(4):215-219.

Garcia M.E., Lanzarot V.L., Rodas V.L., Costas E. \& Blanco J.L. 2007. Fungal flora in the trachea of birds from a wildlife rehabilitation centre in Spain. Vet. Med. 52(10):464-470.

Girolamo N.D., Andreani V., Guandalini A. \& Selleri P.2013. Evaluation of intraocular pressure in conscious ferrets (Mustela putorius furo) by means of rebound tonometry and comparison with applanation tonometry. Vet Rec. 172(15):378-396.

Godoy S.N. 2007. Psittaciformes (Arara, Papagaio, Periquito), p.222-224. In: Cubas Z.S., Silva J.C.R. \& Catão-Dias J.L. (Eds), Tratado de Animais Selvagens: medicina veterinária. Roca. São Paulo. 
Gonzalez-Alonso-Alegre E.M., Martinez-Nevado E., Caro-Vadillo A. \& Rodriguez-Alvaro A. 2015. Central corneal thickness and intraocular pressure in captive black-footed penguins (Spheniscus dermersus). Vet. Ophthalmol. 18(Suppl.1):94-97.

Gwynne J.A., Ridgely R.S., Tudor G. \& Argel M. 2010. Birds of Brazil: the Pantanal and Cerrado of Central Brazil. Editora Horizonte, São Paulo. 114p.

Harris M.C., Schorling J.J., Herring I.P., Elvinger F., Bright P.R. \& Pickett J.P. 2008. Ophthalmic examination findings in a colony of Screech owls $(\mathrm{Me}$ gascops asio). Vet. Ophthalmol. 3(11):186-192.

Hart N.S. 2002. Vision in the peafowl (Aves: Pavo cristatus). J. Exp. Biol. 205:3925-3935.

Hoppes S., Gurfield N., Flammer K., Colitz C. \& Fisher P. 2000. Mycotic keratitis in a Blue-fronted Amazon Parrot (Amazona aestiva). J. Avian Med. Surg. 14(3):185-189.

Hvenegaard A.P., Safatle A.M.V., Guimarães M.B., Ferreira A.J.P. \& Barros P.S.M. 2009. Retrospective study of ocular disorders in Amazon parrots. Pesq. Vet. Bras. 29(12):979-984.

Jeong M.B., Kim Y.J., Yi N.Y., Park S.A., Kim W.T., Kim S.E., Chae J.M., Kim J.T., Lee H. \& Seo K.M. 2007. Comparison of the rebound tonometer (TonoVet $^{\circledR}$ ) with the applanation tonometer (TonoPen $\mathrm{XL}^{\circledR}$ ) in normal Eurasian Eagle owls (Bubo bubo). Vet. Ophthalmol. 10(6):376-379.

Johnson T.V., Fan S. \& Toris C.B. 2008. Rebound Tonometry in Conscious, Conditioned Mice Avoids the Acute and Profound Effects of Anesthesia on Intraocular Pressure. J. Ocul. Pharmacol. Ther. 24(2):175-185.

Kern T.J. \& Colitz C.M.H. 2013. Exotic Animal Ophthalmology: veterinary ophthalmology. Vol.1 e 2. 5th ed. Wiley-Blackwell, Oxford, UK. 2260p.

Korbel R. \& Leitenstorfer P. 1998. The modified Schirmer tear test in birds-a method for checking lacrimal gland function. Tierärztl. Prax. 26(4):284-294.

Kuhn S.E., Jones M.P., Hendrix D.V., Ward D.A. \& Baine K.H. 2013. Normal ocular parameters and characterization of ophthalmic lesions in a group of captive Bald Eagles (Haliaeetus leucocephalus). J. Avian Med. Surg. 27(2):90-98.

Lichtenberger M. \& Ko J. 2007. Anesthesia and analgesia for small mammals and birds. Vet. Clin. North Am., Exotic. 10(2):293-315.

Lima F.C., Vieira L.G., Santos A.L.Q., De Simone S.B.S., Hirano L.Q.L., Silva J.M.M. \& Romão M.F. 2009. Anatomy of the scleral ossicles in Brazilian birds. Braz. J. Morphol. Sci. 26(3/4):165-169.

Machado M., Schmidt E.M.S. \& Montiani-Ferreira F. 2006. Interspecies variation in orbital bone structure of psittaciform birds (with emphasis on Psittacidae). Vet. Ophthalmol. 9(3):191-194.

Martin G.R. \& Shaw J.M. 2010. Bird collisions with power lines: failing to see the way a head? Biol. Conserv. 143(11):2695-2702.

McMurphy R.M., Davidson H.J. \& Hodgson D.S. 2004. Effects of atracurium on intraocular pressure, eye position and blood pressure in eucapnic and hypocapnic isoflurane-anesthetized dogs. Am. J. Vet. Res. 65(2):179-182.

Meekins J.M., Stuckey J.A., Carpenter J.W., Armbrust L., Higbie C. \& Rankin A.J. 2015a. Ophthalmic diagnostic tests and ocular findings in a flock of captive American flamingos (Phoenicopterus ruber ruber). J. Avian Med. Surg. 29(2):95-105.

Meekins J.M., Eshar D. \& Rankin A.J. 2015b. Tear production, intraocular pressure, and conjunctival bacterial flora in a group of captive blacktailed prairie dogs (Cynomys ludovicianus). Vet. Ophthalmol. 18(s.1): 132-136.

Moore C.P. \& Nasisse M.P. 1999. Clinical microbiology, p.259-289. In: Gelatt K.N. (Ed.), Veterinary Ophthalmology. 3rd ed. Lippincott Williams and Wilkins, Philadelphia.
Murphy C.J., Glasser A. \& Howland H.C. 1995. The anatomy of the ciliary region of the chicken eye. Invest. Ophthalmol. Vis. Sci. 36(5):889-896.

Nicolau A.A., Fantoni D.T., Auler J.O. \& Ambrósio A. 2002. 0 sevofluorano em psitacídeos (Amazonas aestiva): determinação da dose mínima (d.a.m) para produção de anestesia geral. Ciência Rural 32(5)781-786.

Pauli A.M., Bentley E., Diehl K.A. \& Miller P.E. 2006. Effects of the application of neck pressure by a collar or harness on intraocular pressure in dogs. J. Am. Anim. Hosp. Assoc. 42(3):207-211.

Rauscher F.G., Azmanis P., Körber N., Koch C., Hübel J., Vetterlein W., Werner B., Thielebein J., Dawczynski J., Wiedemann P., Reichenbach A., Francke M. \& Krautwald-Junghanns M.E. 2013. Optical coherence tomography as a diagnostic tool for retinal pathologies in avian ophthalmology. Invest. Ophth. Vis. Sci. 54(13):8259-8269.

Reuter A., Müller K., Arndt G. \& Eule J.C. 2010. Accuracy and reproducibility of the TonoVet ${ }^{\circledR}$ rebound tonometer in birds of prey. Vet. Ophthalmol. 13:80-85.

Reuter A., Müller K., Arndt G. \& Eule J.C. 2011. Reference intervals for intraocular pressure measured by rebound tonometry in ten raptor species and factors affecting the intraocular pressure. J. Avian Med. Surg. 25(3):165-172.

Rodarte-Almeida A.C.V., Machado M., Baldoso S.B., Santos L.L., Lima L., Lange R.R., Froes T.R. \& Montiani-Ferreira F. 2013. 0 olho da coruja-orelhuda: observações morfológicas, biométricas e valores de referência para testes de diagnóstico oftálmico. Pesq. Vet. Bras. 33(10):1275-1289.

Santos A.A. \& Ragusa-Netto J. 2014. Plant food resources exploited by Blue-and-Yellow Macaws (Ara ararauna, Linnaeus 1758) at an urban area in Central Brazil. Braz. J. Biol. 74(2):429-437.

Seruca C., Molina-López R., Peña T. \& Leiva M. 2012. Ocular consequences of blunt trauma in two species of nocturnal raptors (Athene noctua and Otus scops). Vet. Ophthalmol. 15(4):236-244.

Sgorbini M., Barsotti G., Nardoni S., Mancianti F., Rossi S. \& Corazza M. 2008. Fungal flora of normal eyes in healthy newborn foals living in the same stud for in Italy. J. Equine Vet. Sci. 28(9):540-543.

Sick H. 2001. Ordem Psittaciformes, p.351-368. In: Sick H. (Ed.), Ornitologia Brasileira. 3를 ed. Editora Nova Fronteira, Rio de Janeiro.

Smith S.P., Barbon A.R. \& Forbes N.A. 2015. Evaluation of the phenol red thread tear test in Falconiformes. J. Avian Med. Surg. 29(1):25-29.

Somma A.T., Lima L., Lange R.R., Turner-Giannico A. \& Montiani-Ferreira F. 2015. The eye of the red-eared slider turtle: morphologic observations and reference values for selected ophthalmic diagnostic tests. Vet. Ophthalmol. 18(s.1):61-70.

Swinger R.L., Langan J.N. \& Hamor R. 2009. Ocular bacterial flora, tear production, and intraocular pressure in a captive flock of Humboldt penguins (Spheniscus Humboldti). J. Zoo Wildl. Med. 40(3):430-436.

Valle S.F., Allgayer M.C., Pereira R.A., Barcellos L.J.G., Hlavac N.R.C., França R.T. \& Locatelli M.L. 2008. Parâmetros de bioquimica sérica de machos, fêmeas e filhotes de araras Canindé (Ara ararauna) saudáveis mantidas em cativeiro comercial. Ciência Rural 38(3):711-716.

Williams D.L. 1994. Ophthalmology, p.673-694. In: Ritchie B.W., Harrison G.J. \& Harrison L.R. (Eds), Avian Medicine: principles and application. Winger's Publishing, Lake Worth, FL.

Williams D.L. 2012. Ophthalmology of Exotic Pets. Wiley-Blackwell, Oxford, UK. 248p.

Willis A.M. \& Wilkie D.A. 1999. Avian Ophthalmology. 1. Anatomy, Examination. J. Avian Med. Surg. 3(13):160-166.

Zenoble R.D., Griffith R.W. \& Clubb S.L. 1983. Survey of bacteriologic flora of conjunctiva and cornea in healthy psittacine birds. Am. J. Vet. Res. 10(44):1966-1967. 